\title{
Cytotoxic Effects of Thiazolo[3,2-C]Pyrimidines Against Mcf-7 And Hepg2/C3a Carcinoma Cell Lines
}

\section{Tiyazolo[3,2-C]Pirimidinlerin Mcf-7 ve Hepg2/C3a Kanser Hücre Hatlarına Karşı Sitotoksik Etkileri}

\author{
Research Article
}

Arzu Birinci Yıldırım1, Esra Mutlu², Muhammet Yıldırım*

'Department of Field Crops, Faculty of Agriculture and Natural Sciences, Abant izzet Baysal University, Bolu, Turkey. ${ }^{2}$ Scientific Industrial and Technological Application and Research Center, Abant izzet Baysal University, Bolu, Turkey. ${ }^{3}$ Department of Chemistry, Faculty of Sciences and Arts, Abant Izzet Baysal University, Bolu, Turkey.

\section{A B S TRACT}

$\mathrm{n}$ the present study, a series of thiazolo[3,2-c]pyrimidines $(4,5)$ have been produced via simple and efficient synthetic method and their in vitro cytotoxicities have been performed on human breast (MCF-7) and hepatocellular (HEPG2/C3A) adenocarcinoma cell lines. The results of these in vitro tests revealed that at least five of thiazolo[3,2-c]pyrimidines exhibited strong cytotoxic effects at very low concentrations, which were very similar or lower than that of reference anticancer agent, 5-FU, against MCF-7 and HEPG2/C3A cancer cell lines.

\section{Key Words}

Anticancer, breast cancer, Mannich cyclisation, thiazolopyrimidines.

\section{öz}

\begin{abstract}
alışmamızda, yeni tiyazolo[3,2-c]pirimidinlerin $(4,5)$ bir serisi, basit ve etkili bir yöntemle hazırlandı ve bu 3 bileşiklerin in vitro sitotoksisiteleri insan meme (MCF-7) ve karaciğer (HEPG2/C3A) kanser hücre hatları üzerinde çalışıldı. In vitro çalışma sonuçları, tiyazolo[3,2-c]pirimidinlerin en az 5 tanesinin düşük derişimlerde MCF-7 ve HEPG2/C3A kanser hücre hatlarına karşı kuvvetli sitotoksik etki gösterdiğini ortaya koymaktadır ki bu etki kullanılan referans antitümör ajanın, 5-FU, etkisiyle aynı veya daha düşüktür.
\end{abstract}

\section{Anahtar Kelimeler}

Antikanser, meme kanseri, Mannich halkalaşması, tiyazolopirimidinler.

Article History: Received: Nov 21, 2017; Revised: Dec 08, 2017; Accepted: Feb 16, 2018; Available Online: Mar 26, 2018

DOI: 10.15671/HJBC.2018.232

Correspondence to: M. Yıldırım, Dept. of Chemistry, Faculty of Sciences and Arts, Abant izzet Baysal University, Bolu, Turkey . 


\section{INTRODUCTION}

The he active agents used for cancer therapy have not been diversified too much overtime. Although in last decades, great efforts have been performed for the preparation of more precise and smart synthetic ones, which may bring a new hope for cancer patients during chemotherapy and diagnosis phases [1]. The popular active agents such as doxorubicin (DOX), camptothecin, paclitaxel (or docetaxel), 5-fluorouracil (5-FU) have been widely used with broad spectrum of antitumor effects since 1960s [1-3]. They exhibit anticancer effects by various mechanisms such as breaking the strands of DNA double helix, interfering with the religation of DNA and interrupting the feeding and proliferation of cancer cells by division $[2,4-7]$.

Over many years, aforementioned anticancer agents (paclitaxel, docetaxel, camptothecin, doxorubicin) have been used for cancer treatments, but their higher dose toxicities, side effects, and also, the difficulties originated from their multistep preparations sometimes diminished their use as cancer therapeutics [810]. Thereof, the development of new molecules, which are able to do much stronger apoptosis and have less toxic effects with much simpler synthetic methodologies, have gain much more importance recently.

Among the well-known anticancer drugs, 5-fluorouracil (5-FU) is a cancer antimetabolite and structurally similar to thiazolopyrimidines which consisted of a thiazole and a pyrimidine ring. Thiazolopyrimidines are known to display many important biological properties such as antimicrobial, antipsychotic, anti-inflammatory, antiparkinson, antidepressant and anti-HIV especially anticancer activities [11-13].

Today, three main classes of thiazolopyrimidines are known to exist in chemical literature [14] and two of the main structural classes; thiazolo[4,5-d]pyrimidines and thiazolo[3,2-a]pyrimidines, have been extensively utilized in many types of cytotoxic activity studies. Besides, a diverse range of anticancer or antitumor thiazolopyrimidines in these two main classes have been identified due to their strong cytotoxic effects against various carcinoma cell lines such as HepG-2 (liver), PC-3 (prostate), HCT-116 (colon), A549 (lung), A431 (epidermal), T98G (glioblastoma), HL-60 (leukemia), SF-268 (CNS) and MCF-7(breast) [15-20]. For instance, some new thiazolo[3,2-a]pyrimidines have been developed as CDC25 phosphatase inhibitors and have displayed very strong cytotoxicity against HeLa cells at very low concentrations [21]. In another antitumor study of newly developed pyrrolothiazolo- and triazolopyrrolo[3,2-a]pyrimidinones, good cyctotoxic effects have been obtained against ascite tumor cells in mice [22]. In 2015, Yahya et al. found that the arylidenethiazolo[3,2-a]pyrimidinones exhibited strong cytotoxic effects at very low concentrations against breast tumor cell lines [18]. In a more recent study, new pyridothiazolo[3,2-a] pyrimidines have been evaluated in vitro against HepG-2, PC-3 and HCT-116 cancer cell lines and some halogenated thiazolo[3,2-a]pyrimidines have been found to exhibit cytotoxic effects on HCT-116 cancer cell lines [19].

In similar fashion, many different cytotoxicity studies of thiazolo[4,5-d]pyrimidines have been carried out against a variety of cancer cell lines. For instance, in the study of Lin and coworkers (2009), some 2,7-diaminothiazolo[4,5-d] pyrimidines have been evaluated to determine their potency, selectivity and bioavailability as EGFR kinase inhibitors [16]. Three of the derivatives exhibited antiproliferative activity on human ovarian adenocarcinoma (SK-OV-3) cells at very low micromolar concentrations. Also, in the recent work of Singh et al. (2013), new 2-amino-7-chlorothiazolo[4,5-d]pyrimidines have been screened against lung ( $\mathrm{NCl}-\mathrm{H} 322$ and A549), epidermal (A431), glioblastoma (T98G), pancreatic (MIAPaCa-2), prostate (PC-3), human leukemia (HL-60) and breast (T47D) cell lines[17]. One molecule exhibited antiproliferative activity against lung ( $\mathrm{NCl}-\mathrm{H} 322$ and $\mathrm{A} 549$ ), epidermal (A431), glioblastoma (T98G) cells at relatively low concentrations and two molecules were very cytotoxic against lung (A549) and human leukemia (HL-60) cell lines.

Thiazolo[3,2-c]pyrimidines, being the last main class of thiazolopyrimidines, are very 


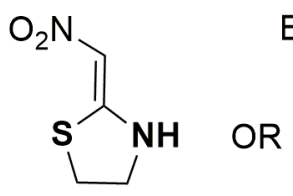

$1 \mathrm{a}$

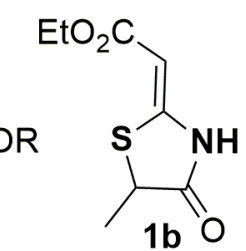

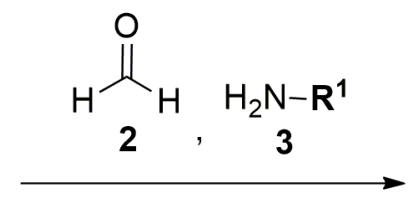

$\mu \mathrm{W}$ or conv. heating

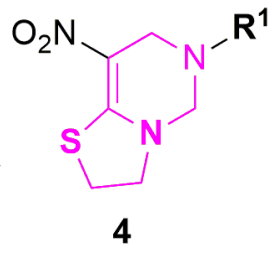

OR

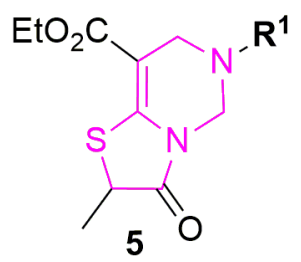

Figure 1. General method for preparation of thiazolo[3,2-c]pyrimidines (4a-d,5a-k).

new derivatives and unstudied in the sense that no cytotoxicity study is present in the literature. With this in mind, very recently, a series of nitrothiazolo[3,2-c]pyrimidines (4) and oxothiazolo[3,2-c]pyrimidine carboxylates (5) have been produced via simple and efficient methods resulting in excellent yields by our group for the first time[14,23]. Whereupon, in the present work, successive in vitro cytotoxic activity studies of thiazolo[3,2-c]pyrimidines $(4,5)$ at varying concentrations have been performed against human breast (MCF-7) and hepatocellular (HEPG2/C3A) adenocarcinoma cell lines. The results of in vitro tests revealed that mostly the oxothiazolo[3,2-c]pyrimidine carboxylates (5) exhibited better cytotoxic effects than nitrothiazolo[3,2-c]pyrimidines (4) against both MCF-7 and HEPG2/C3A carcinoma cell lines.

\section{MATERIALS and METHODS}

\section{Chemicals and Equipments}

All the necessary reagents, chemicals and the solvents were purchased in analytical and reagent grades (Merck, Sigma-Aldrich). Reactions were monitored with precoated TLC plates (Merck 5735) and column chromatography were performed for purifications of title compounds by using silica gel 60 (Merck 109385). Starting materials, 2-(nitromethylene)thiazolidine (1a) and (Z)-ethyl 2-(5-methyl-4-oxothiazolidin-2-ylidene) acetate (1b), were prepared and characterized according to reported methods $[14,24]$.

\section{Preparation of Thiazolo[3,2-c]pyrimidines (4a-d, 5a-k). [14,25,23]}

General method: One equivalent amount of 2-(nitromethylene)thiazolidine, (1a) or (Z)-ethyl 2-(5-methyl-4-oxothiazolidin-2-ylidene)acetate (1b) and primary amine (3) were dissolved in acetonitrile (or water), then, two equivalents of formaldehyde (2) was added dropwise and resulting mixture was refluxed (or irradiated in a microwave reactor) under inert atmosphere until reaction completion in 3-4 $\mathrm{h}$ (or 3-4 min) (Figure 1). After work-up, final products (4 or 5) were purified by flash column chromatography on silica gel or recrystallization from suitable solvents and obtained in excellent yields. ${ }^{1} \mathrm{H}-\mathrm{NMR}$ and ${ }^{13} \mathrm{C}$-NMR spectral data confirmed the structures of title compounds, 4a-d and 5a-k [14,23,25].

\section{In Vitro Cytotoxic Activity Studies of Thiazolo[3,2-c]pyrimidines \\ Cell Preparation and Culturing}

Human breast (MCF-7) and hepatocellular (HEPG2/ C3A) adenocarcinoma cell lines were obtained from Abant izzet Baysal University, Faculty of Medicine, Department of Pharmacology. The cells were maintained in Dulbecco's modified eagle's medium (DMEM, Invitrogen) containing 10\% fetal bovine serum (FBS) and $100 \mathrm{ng} / \mathrm{ml}$ of penicillin and streptomycin (Sigma). Cells were allowed to grow in tissue culture flasks and were kept in a $\mathrm{CO}_{2}$ incubator at $37^{\circ} \mathrm{C}$ in a humidified atmosphere of $5 \% \mathrm{CO}_{2}$ and $95 \%$ air.

\section{Cell Viability with MTT Assay [26]}

The MTT assay is based on the reduction of yellow 3-(4,5-dimethylthiazol-2-yl)-2,5-diphenyl tetrazolium bromide (MTT) to purple formazan in living cells which corresponds to the activity of mitochondria and this color change is subsequently measured at $570 \mathrm{~nm}$. For the assay, about $1 \times 10^{4}$ viable cells in $100 \mu$ of culture medium (DMEM) were added to each well in of a 96-well cell culture plate. The plates were allowed to incubate for 16 hours at $37^{\circ} \mathrm{C}$ under $5 \% \mathrm{CO}_{2}$ in a humidified incubator allowing the cells to attach the 96-well cell culture plates. After the cell attachment was checked, the cells were treated with serial concentrations of thiazolo[3,2-c] pyrimidine compounds $(4,5)$ and then incubated for 24-72 h [26]. 
Thiazolo[3,2-c]pyrimidines were initially dissolved in $0.5 \%$ DMSO by adjusting the concentration of the compounds to 500,300 , 200, 100, 10, $1 \mu \mathrm{M}$. Likewise, 5-fluorouracil (5-FU) concentrations were adjusted to 500, 300, 200, $100,10,1 \mu \mathrm{M}$ in $0.5 \%$ DMSO. The plates were incubated for 24,48 and $72 \mathrm{~h}$. After incubation periods, the culture medium was removed and replaced with $90 \mu \mathrm{L}$ of fresh culture medium (DMEM). Then, $10 \mu \mathrm{L}$ of MTT solution $(5 \mathrm{mg} / \mathrm{ml}$ ) in phosphate buffered saline (PBS, $\mathrm{pH}$ 7.4) was added to each well and the final concentration of MTT of $0.5 \mathrm{mg} / \mathrm{L}$ which was allowed to incubate at $37^{\circ} \mathrm{C}$, in a $5 \% \mathrm{CO}_{2}$ humidified incubator for $4 \mathrm{~h}$. After $4 \mathrm{~h}$ incubation, $100 \mu \mathrm{L} /$ well of DMSO were added to all samples for dissolving the formazan that is the final product of MTT reaction and were allowed to incubate at $37^{\circ} \mathrm{C}$, in a $5 \% \mathrm{CO}_{2}$ humidified incubator for overnight. After incubation, absorbance of formazan was measured spectrophotometrically in a Multiskan FC microplate photometer reader at $570 \mathrm{~nm}$ Each experiment was carried out in triplicate. $0.5 \%$ DMSO and PBS was used as negative control groups. The percent cytotoxicities of thiazolo[3,2-c]pyrimidines (\% cell viability) were calculated according to their control groups as;

$\%$ cell viability $=100 \times \mathrm{A} 570 \mathrm{~nm}$ (sample) $/ \mathrm{A} 570$ $\mathrm{nm}$ (control)

All data were analyzed by ANOVA with the last factor as a within subject or repeated design using SPSS version 15 (SPSS Inc., Chicago, IL, USA). Values were considered statistically significant at $p \leq 0.05$. The data were presented as mean \pm standard error (SE) after back transforming from ANOVA results. $I_{50}$ of the compounds were determined by plotting triplicate data points over a concentration range and calculating values using regression analysis of SPSS program.

\section{RESULTS and DISCUSSION}

\section{Preparation of Thiazolo[3,2-c]pyrimidines (4,} 5)

Synthesis of thiazolo[3,2-c]pyrimidines (4 or 5) were performed via three-component reaction of enamines 1a, 1b with corresponding primary aryl or alkyl amines (3) and formaldehyde (2) as described in material and method part. The structures of purified compounds 4 and 5 given in Figure 2 were characterized by ${ }^{1} \mathrm{H}$ - and ${ }^{13} \mathrm{C}$-nuclear magnetic reasonance (NMR) and high-resolution mass (HR-MS) analyses. Spectroscopic data of title compounds 4 and 5 were consistent with the literature data.[14,23].

\section{MTT Assay with Thiazolo[3,2-c]pyrimidines against MCF-7 and HEPG2/C3A Cell lines}

As reported in literature, thiazolopyrimidinebased compounds exhibited good cytotoxic effects against various human carcinoma cell lines $[16,17,18,19,22]$ (Abdel-Latif, Sabry et al. 2007). In the present study, we were interested to find out whether thiazolo[3,2-c]pyrimidines $(4,5)$ would exhibit similar and stronger cytotoxic effects against human breast and hepatocellular adenocarcinoma cell lines as much as the

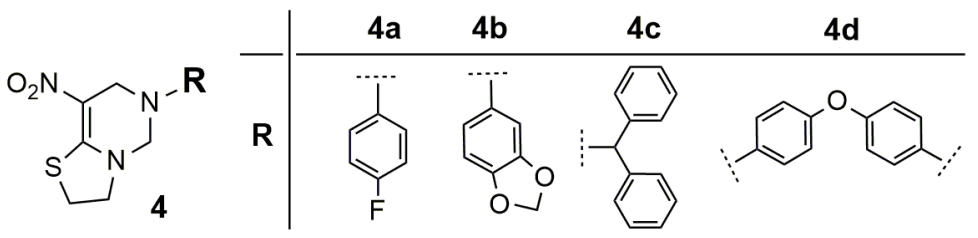

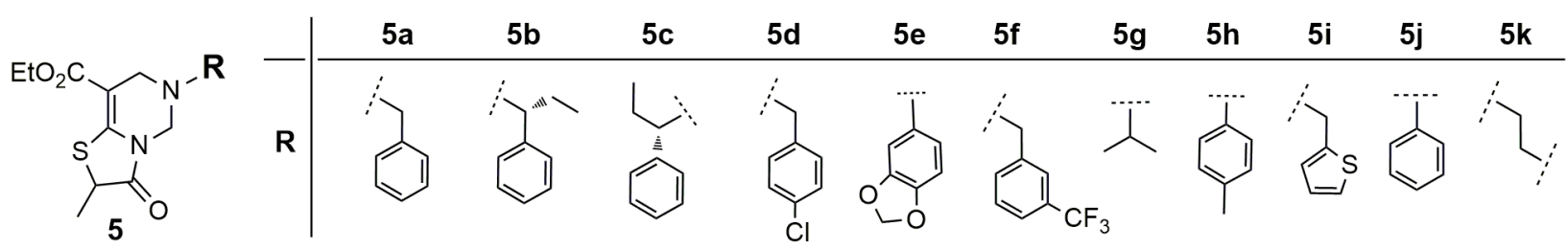

Figure 2. Prepared thiazolo[3,2-c]pyrimidines (4a-d, 5a-k) for cytotoxicity studies. 
derivatives which belong to two other main classes of thiazolopyrimidines. Thus, fifteen thiazolo[3,2-c]pyrimidines (4a- $d, 5 a-k)$ along with 5-FU (reference anticancer agent) were investigated through different concentrations $(1,10,100 \mu \mathrm{M})$ for their cytotoxic effects against MCF-7 cancer cell line in a $72 \mathrm{~h}$ cell viability test. Three different concentrations of thiazolo[3,2-c] pyrimidines were adjusted in $0.5 \%$ DMSO to a final concentration of $1,10,100 \mu \mathrm{M}$ prior to determine their cytotoxic effects. Cytotoxicities of the compounds were calculated according to percentage viability of MCF-7 cells in $0.5 \%$ DMSO after 72 h. $0.5 \%$ DMSO was also used as the negative control and 5-FU was used as positive control due to its structural similarity to thiazolo[3,2-c]pyrimidines. According to the results of $72 \mathrm{~h}$ cell viability test, at $100 \mu \mathrm{M}$ concentration, five of thiazolo[3,2-c]pyrimidines $(4 d, 5 d, 5 f, 5 h, 5 j)$ containing meta-, parasubtituted phenyl and benzyl groups was found to exhibit the strong to moderate cytotoxic effects against MCF-7 cells when compared to reference antitumor agent (5-FU) (Table 1, Figure 3). At $10 \mu \mathrm{M}$ concentration level, compound $4 \mathrm{~d}$ (p-oxyphenyl substituted) exhibited the best but the moderate cytotoxic effect and compound 4b (3,4-methylenedioxyphenyl substituted) exhibited similar cytotoxicity as that of reference anticancer agent (5-FU) against MCF-7 cell lines. Hovewer, at $1 \mu \mathrm{M}$ concentration level, there were no significant difference between cell viability test results of the compounds and antitumor agent, 5-FU. The results of $72 \mathrm{~h}$ cell viability test showed that three derivatives, $5 \mathrm{j}$ (phenyl substituted), $5 f$ (3-CF -benzyl substituted), $5 d$ ( $p$-Cl-benzyl substituted) exhibited the strongest and two derivatives $4 \mathrm{~d}$ ( $\mathrm{p}$-oxyphenyl substituted), $5 \mathrm{~h}$ ( $p$-methylphenyl substituted) exhibited less strong cytotoxic effects against MCF-7 cell lines (Table 1).

Table 1. Cytotoxic effects of thiazolo[3,2-c]pyrimidines against MCF-7 Cell Lines for $72 \mathrm{~h}$.

\begin{tabular}{|c|c|c|c|}
\hline \multirow[t]{2}{*}{ Treatments } & \multicolumn{3}{|c|}{ \% Cell Viabilitya } \\
\hline & $1 \mu \mathrm{M}$ & $10 \mu \mathrm{M}$ & $100 \mu \mathrm{M}$ \\
\hline $4 a$ & $103.14 \pm 2.31$ & $93.79 \pm 2.31$ & $77.02 \pm 4.99$ \\
\hline $4 b$ & $91.98 \pm 4.87$ & $85.77 \pm 4.36$ & $65.16 \pm 4.06$ \\
\hline $4 c$ & $110.86 \pm 0.28$ & $97.96 \pm 0.40$ & $95.30 \pm 4.52$ \\
\hline $4 d$ & $100.99 \pm 3.30$ & $66.71 \pm 3.53$ & $52.97 \pm 3.99$ \\
\hline $5 a$ & $110.95 \pm 8.20$ & $107.95 \pm 4.63$ & $72.47 \pm 2.73$ \\
\hline $5 b$ & $111.67 \pm 4.07$ & $108.50 \pm 1.89$ & $84.95 \pm 2.63$ \\
\hline $5 c$ & $114.63 \pm 1.41$ & $113.66 \pm 4.93$ & $70.95 \pm 4.36$ \\
\hline $5 d$ & $116.30 \pm 2.89$ & $110.61 \pm 3.46$ & $49.77 \pm 2.10$ \\
\hline $5 e$ & $113.57 \pm 1.91$ & $108.71 \pm 7.20$ & $61.48 \pm 3.39$ \\
\hline $5 f$ & $116.83 \pm 6.43$ & $99.79 \pm 6.12$ & $46.98 \pm 2.48$ \\
\hline $5 g$ & $97.73 \pm 2.44$ & $91.66 \pm 7.86$ & $87.24 \pm 2.12$ \\
\hline $5 \mathrm{~h}$ & $92.33 \pm 5.33$ & $91.48 \pm 8.80$ & $57.45 \pm 5.33$ \\
\hline $5 i$ & $102.33 \pm 4.33$ & $97.77 \pm 4.64$ & $67.20 \pm 1.11$ \\
\hline $5 j$ & $102.94 \pm 8.44$ & $103.45 \pm 4.41$ & $45.75 \pm 0.80$ \\
\hline $5 k$ & $114.71 \pm 3.94$ & $109.23 \pm 9.98$ & $65.18 \pm 2.26$ \\
\hline $5-F U$ & $108.16 \pm 8.24$ & $85.48 \pm 5.31$ & $47.65 \pm 5.46$ \\
\hline
\end{tabular}

${ }^{a}$ Mean values ( \pm standard deviation) for triplicate assays. 


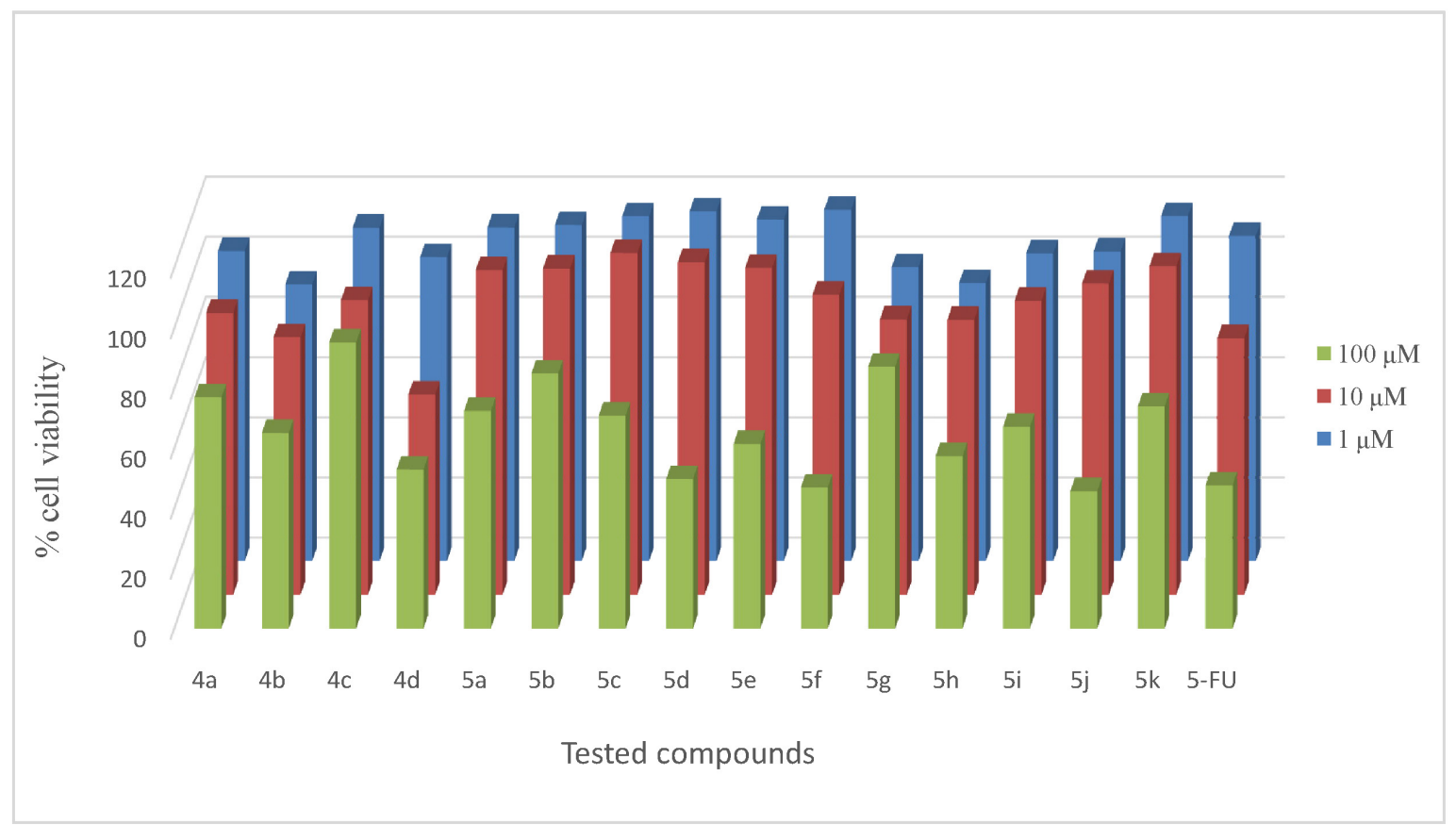

Figure 3. Cytotoxic activities of thiazolo[3,2-c]pyrimidines against MCF-7 Cell lines in $72 \mathrm{~h}$.

Table 2. Cytotoxic effects of thiazolo[3,2-c]pyrimidines against MCF-7 Cell Lines for $24 \mathrm{~h}$.

Treatment $\quad \%$ Cell Viability ${ }^{a}$

\begin{tabular}{ccccccc}
\hline & 500 & 300 & 200 & 100 & 10 & 1 \\
& $\mu \mathrm{M}$ & $\mu \mathrm{M}$ & $\mu \mathrm{M}$ & $\mu \mathrm{M}$ & $\mu \mathrm{M}$ & $\mu \mathrm{M}$ \\
\hline $5 \mathrm{~d}$ & $64.25 \pm 3.48$ & $73.42 \pm 6.99$ & $87.33 \pm 0.84$ & $98.44 \pm 0.21$ & $109.55 \pm 3.39$ & $92.80 \pm 6.44$ \\
\hline $5 f$ & $52.54 \pm 3.18$ & $60.52 \pm 2.26$ & $82.15 \pm 2.35$ & $96.31 \pm 7.39$ & $87.38 \pm 6.74$ & $122.39 \pm 7.77$ \\
\hline $5 j$ & $75.36 \pm 2.71$ & $86.60 \pm 0.21$ & $96.88 \pm 0.07$ & $109.99 \pm 4.80$ & $112.17 \pm 7.54$ & $111.67 \pm 5.65$ \\
\hline
\end{tabular}

a Mean values ( \pm standard deviation) for triplicate assays.

As a toxicity parameter, $I C_{50}$ values of $5 d, 5 f$, $5 j$ derivatives that show $\% 50$ inhibition of cell proliferation and of 5-FU were calculated. They corresponded to $99 \mu \mathrm{M}, 94 \mu \mathrm{M}$ and $92 \mu \mathrm{M}$, respectively (Table 4). Calculated IC $\mathrm{C}_{50}$ value of 5-FU (85 $\mu \mathrm{M}$ ) complies with its other published literature data against human breast cancer cell lines (MCF7) [27-32]. Twelve other derivatives (4a-c, $5 a-c$, $5 e, 5 g-i, 5 k)$ showed moderate to weak cytotoxic activities (53-87\% cell viability) (Table 1$)$ and so, their $I_{50}$ values were obtained higher than $100 \mu \mathrm{M}$ which were not very significant results for this test.

A further cytotoxicity study in different concentrations $(1,10,100,200,300,500 \mu \mathrm{M})$ of the most cytotoxic compounds $(5 \mathrm{~d}, 5 \mathrm{f}, 5 \mathrm{j})$, which were found at $100 \mu \mathrm{M}$ concentration in $72 \mathrm{~h}$ viability test, was performed aganist MCF-7 cell lines for 24 and $48 \mathrm{~h}$. The aim of 24 or $48 \mathrm{~h}$ cell viability tests were to reveal whether the tested compounds may exhibit much stronger or weaker cytotoxicities at lower concentrations in shorter time periods. As it is expected, all tested compounds exhibited moderate cytotoxic effects against MCF-7 cell lines only at higher concentrations $(>300 \mu \mathrm{M})$ in $24 \mathrm{~h}$ test. Unfortunately, all tested compounds did not provide significant cytotoxic effects at concentrations lower than $100 \mu \mathrm{M}$ in $24 \mathrm{~h}$ (Table 2). Since percentage cell viabilities of the tested compounds were not under $\% 50$ at all concentrations, IC $C_{50}$ values of the compounds ( $5 d$, $5 f, 5 j)$ were considered over $500 \mu \mathrm{M}$ in $24 \mathrm{~h}$ test (Table 2,4$)$. Besides, the results of $48 \mathrm{~h}$ cell viability test were meaningless and inconsistent within each other, so their data were not presented, and 
also the $I_{50}$ values of the compounds were not considered for this test.

Lastly, three most cytotoxic compounds ( $5 \mathrm{j}$, $5 f, 5 d)$ and 5-FU through different concentrations $(1,10,100,200,300,500 \mu \mathrm{M})$ were investigated for their cytotoxicities against HEPG2/C3A cancer cell lines in 24,48 and $72 \mathrm{~h}$ cell viability tests. In $24 \mathrm{~h}$ cell viability test, significant cytotoxic effects were only observed for the compounds $5 \mathrm{~d}$ ( $\mathrm{p}$-Cl-benzyl substituted) and $5 \mathrm{f}\left(3-\mathrm{CF}_{3}\right.$-benzyl substituted) at higher concentrations $(>300 \mu \mathrm{M})$ (Table 3, $24 \mathrm{~h}$ treatment). However, in $48 \mathrm{~h}$ cell viability test, only the compound $5 \mathrm{~d}$ ( $\mathrm{p}$-Cl-benzyl substituted) showed moderately strong cytotoxic effect at $100 \mu \mathrm{M}$ concentration against HEPG2/ C3A cell lines. In addition, the compounds $5 \mathrm{~d}$ and $5 f$ exhibited much stronger cytotoxic effects at higher concentrations $(300,500 \mu \mathrm{M})$ when compared to the effect of compound $5 j$ (phenyl substituted). Nevertheless, cytotoxic effect of compounds at higher concentrations are not considered as significant effects against cancer cell lines. The compound $5 \mathrm{j}$ (phenyl substituted) showed moderate to weak cytotoxicities against HEPG2/C3A cell lines at all concentrations. In $72 \mathrm{~h}$ test, two compounds $5 \mathrm{~d}$ ( $\mathrm{p}$-Cl-benzyl substituted), $5 f$ (3- $\mathrm{CF}_{3}$-benzyl substituted) exhibited strong cytotoxic effects against HEPG2/C3A cell lines at $100 \mu \mathrm{M}$ concentration levels, but the cytotoxic effect of compound 5j (phenyl substituted) was moderate (Table 3,72 h treatment). At 10 and $1 \mu \mathrm{M}$ concentration levels, cytotoxic effects of compounds $5 \mathrm{~d}$ ( $\mathrm{p}$-Cl-benzyl substituted) and $5 \mathrm{f}$ (3- $\mathrm{CF}_{3}$-benzyl substituted) have changed from moderate to strong against HEPG2/C3A cell lines and the cell viabilities were obtained as $60-61 \%$ for $5 \mathrm{~d}$ ( $\mathrm{p}$-Cl-benzyl substituted) and $55-59 \%$ for 5f (3- $\mathrm{CF}_{3}$-benzyl substituted) (Table 3, 72-hour treatment).

Since the percentage cell viabilities of compound $5 \mathrm{~d}$ ( $\mathrm{p}$-Cl-benzyl substituted) decreased to $\% 47$ only at $200 \mu \mathrm{M}$ in 48 -hour test and to $\% 49$ at $100 \mu \mathrm{M}$ in $72 \mathrm{~h}$ test, the $\mathrm{IC}_{50}$ values $(128.9 \mu \mathrm{M}$ and $34.6 \mu \mathrm{M})$ of the compound $5 d$ were calculated for these tests (Table 4). However, the percentage cell viabilities of the compounds $5 \mathrm{j}$ (phenyl substituted) and $5 \mathrm{f}\left(3-\mathrm{CF}_{3}\right.$ benzyl substituted) for 24 and $72 \mathrm{~h}$ tests and of the compound $5 \mathrm{~d}$ for $24 \mathrm{~h}$ test did not decrease under $\% 50$ at concentrations lower than $200 \mu \mathrm{M}$ (Table 3). Therefore, $I_{50}$ values of the compounds $5 j, 5 f$ and $5 \mathrm{~d}$ were considered over $500 \mu \mathrm{M}$ for the specified tests. Similarly, the $I_{50}$ values of the compounds $5 f$ and $5 j$ were found at higher concentrations $(186 \mu \mathrm{M}$ and $370 \mu \mathrm{M})$ for $48 \mathrm{~h}$ viability test against HEPG2/C3A cell lines (Table 4).

Table 3. Cytotoxic effects of thiazolo[3,2-c]pyrimidines against HEPG2/C3A Cell Lines for 24-72 h.

\begin{tabular}{cccccccc}
\hline Treatments & \multicolumn{7}{c}{ \% Cell Viability } \\
\hline & & $500 \mu \mathrm{M}$ & $300 \mu \mathrm{M}$ & $200 \mu \mathrm{M}$ & $100 \mu \mathrm{M}$ & $10 \mu \mathrm{M}$ & $1 \mu \mathrm{M}$ \\
\hline $24 \mathrm{~h}$ & $5 \mathrm{~d}$ & $56.25 \pm 3.18$ & $57.61 \pm 3.32$ & $70.02 \pm 0.42$ & $77.40 \pm 1.55$ & $89.15 \pm 0.63$ & $99.66 \pm 0.35$ \\
\hline & $5 f$ & $53.02 \pm 1.41$ & $54.59 \pm 2.68$ & $60.45 \pm 1.23$ & $94.85 \pm 0.28$ & $109.84 \pm 0.42$ & $104.59 \pm 3.60$ \\
\hline $48 \mathrm{~h}$ & $5 \mathrm{~d}$ & $66.87 \pm 0.82$ & $92.28 \pm 1.06$ & $95.53 \pm 0.84$ & $100.11 \pm 4.31$ & $95.19 \pm 2.47$ & $100.34 \pm 2.89$ \\
\hline & $5 f$ & $23.96 \pm 3.39$ & $31.41 \pm 0.98$ & $57.23 \pm 0.76$ & $81.15 \pm 0.35$ & $82.83 \pm 0.42$ & $104.82 \pm 0.63$ \\
\hline $72 \mathrm{~h}$ & $5 \mathrm{~d}$ & $36.33 \pm 3.47$ & $59.02 \pm 4.78$ & $78.67 \pm 6.67$ & $80.64 \pm 0.98$ & $80.06 \pm 0.14$ & $93.64 \pm 3.67$ \\
\hline & $5 \mathrm{~d}$ & $28.32 \pm 2.48$ & $38.52 \pm 5.32$ & $48.84 \pm 3.25$ & $49.36 \pm 1.13$ & $61.82 \pm 3.86$ & $60.36 \pm 1.14$ \\
\hline & $5 f$ & $56.15 \pm 2.47$ & $63.71 \pm 4.31$ & $52.85 \pm 2.76$ & $53.74 \pm 5.55$ & $59.42 \pm 0.63$ & $55.72 \pm 1.13$ \\
\hline & $5 j$ & $68.16 \pm 3.29$ & $79.02 \pm 5.58$ & $89.85 \pm 7.21$ & $65.52 \pm 0.05$ & $67.15 \pm 0.63$ & $72.83 \pm 7.56$ \\
\hline
\end{tabular}

${ }^{a}$ Mean values ( \pm standard deviation) for triplicate assays. 
Table 4. Calculated IC $C_{50}$ value of compounds $5 \mathrm{~d}, 5 \mathrm{f}, 5 \mathrm{j}$ and 5 -FU against MCF-7 and HEPG2/C3A cell lines.

\begin{tabular}{|c|c|c|c|}
\hline \multirow[b]{2}{*}{ Treatments } & \multicolumn{3}{|c|}{$\mathrm{IC}_{50} \pm \mathrm{SEM}(\mu \mathrm{M})$} \\
\hline & $24 \mathrm{~h}$ & $48 \mathrm{~h}$ & $72 \mathrm{~h}$ \\
\hline $5-F U$ & n.t. & n.t. & $85.1 \pm 4.4$ \\
\hline $5 d$ & $>500$ & $>500$ & $99.7 \pm 4.6$ \\
\hline $5 f$ & $>500$ & $>500$ & $94.2 \pm 4.6$ \\
\hline $5 j$ & $>500$ & $>500$ & $92.6 \pm 4.5$ \\
\hline $5 d$ & $>500$ & $128.9 \pm 4.9$ & $34.6 \pm 3.5$ \\
\hline $5 f$ & $>500$ & $186.3 \pm 5.2$ & $>500$ \\
\hline $5 j$ & $>500$ & $370.9 \pm 5.9$ & $>500$ \\
\hline
\end{tabular}

n.t: no treatment. $I C_{50}$ : Concentration of extract that cause $50 \%$ inhibition of cell proliferation.
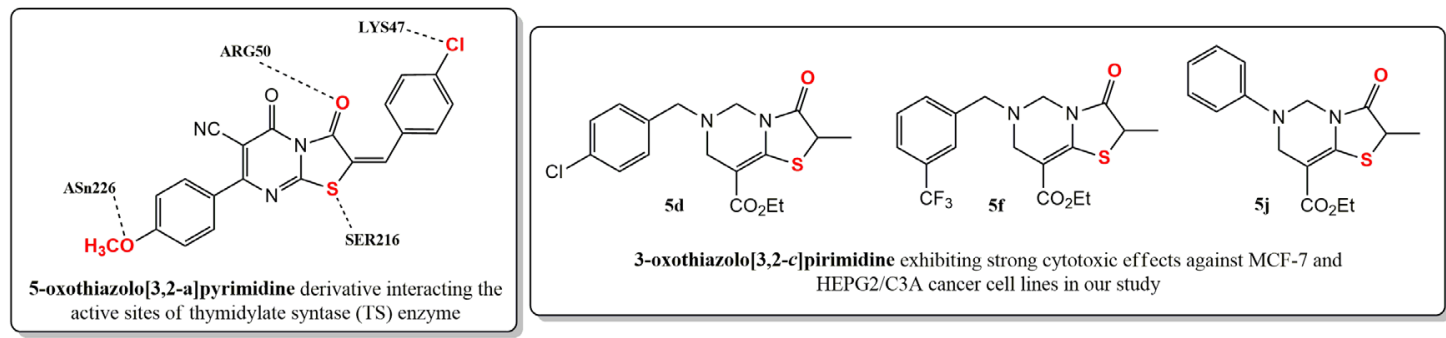

Figure 4.5-oxothiazolo[3,2-a]pyrimidine interacting with the active sites of TS enzyme over 4 hydrogen bonding and title compounds $5 d, 5 f, 5 j$ exhibiting strong cytotoxic effect in our work.

According to the cell viability test results of nitrothiazolo[3,2-c]pyrimidines (4) against MCF-7 cancer cell lines, only the compound $4 d$ exhibited significant cytotoxic effect (53\% at 100 $\mu \mathrm{M})$ and this activity may be attributed to the bis(methyleneoxyphenyl) group in the molecule. However, oxothiazolo[3,2-c]pyrimidines showed better cytotoxic effects against both MCF-7 and HEPG2/C3A carcinoma cell lines at lower concentrations. The promising results obtained may be attributed to para-chlorobenzyland meta-trifluoromethylbenzyl-substitutions on 6-position of thiazolo[3,2-c]pyrimidine derivatives $5 \mathrm{~d}(50 \%)$ and $5 \mathrm{f}(47 \%)$ at $100 \mu \mathrm{M}$, respectively. And also, p-methylphenyl- and phenyl-substituted derivatives $(5 \mathrm{~h}, 57 \%$ and $5 \mathrm{j}, 46 \%$ at $100 \mu \mathrm{M})$ exhibited strong cytotoxic effects. Alkyl substitution or some other aryl substituted benzyl and phenyl groups in compounds 4 and 5 did not result in any significant activity other than moderate or weak, and sometimes, proliferative effects were also observed.
In a very recent cytotoxicity study of 5-oxothiazolo[3,2-a]pyrimidines, stronger cytotoxic effects were obtained against MCF7 and HEPG 2 cancer cell lines as compared to reference anticancer agent, $5-\mathrm{FU}$. Since $5-\mathrm{FU}$ is in similar structure to thiazolopyrimidines and it stopped DNA synthesis by inhibiting thymidylate synthase (TS) enzyme, the binding affinities of the most cytotoxic 5-oxothiazolo[3,2-a] pyrimidine and 5-FU were investigated to enzyme active sites by molecular docking. Hydrogen bonding interactions of $\mathrm{S}$ atom in thiazolidinone ring with aminoacid Ser216 residue and of $\mathrm{O}$ atom with aminoacid Arg50 residue were identified with other two interactions [36]. Regarding the interactions of 5-oxothiazolo[3,2-a]pyrimidine found by docking studies and its structural similarity to the compound $5 \mathrm{~d}$ (para-chlorophenyl substitution) in our study, the reason why strong cytotoxic effects were obtained against MCF-7 and HEPG2 cell lines in our work can be explained (Figure 4). 
In other recent studies supporting our findings, p-methoxy- or dimethoxy-phenyl subtituted thiazolopyrimidine analogues showed moderate cytotoxic acitivities against HEPG2 and MCF-7 cell lines [33]. Similarly, p-MeO, p-Cl-phenyl substituted arylthiazolopyrimidines displayed very strong cytotoxic effects against MCF-7 cell lines [16]. In addition, phenylsulfonamidosubstituted thiazolo[3,2-a]pyrimidines demonstrated very significant antitumor activities against colon cancer-HT-29, human liver-HEPG2 and MCF-7 cell lines at very low concentrations [34]. Also, some aryl and benzyl substituted 2-thioxothiazolo[4,5-d]pyrimidinones were found to be significantly active against lung$\mathrm{NCl}-\mathrm{H}-460$, breast-MCF-7 and CNS-SF-268 cancer cell lines [35].

\section{CONCLUSIONS}

The current cytotoxicity study contains some novel findings. We believe that this work provides the first, most current and up-to-date cytotoxicity data (concentration, $\mathrm{IC}_{50}$ etc.) regarding 6-aryl or benzyl substituted thiazolo[3,2-c]pyrimidines, particularly on human breast and hepatocellular carcinoma cell lines, since there was no biological activity, in particular antiproliferative or cytotoxic activity, of thiazolo[3,2-c]pyrimidines reported before the current cytotoxicity study of title compounds $(4,5)$. Besides, this study clearly explains the cytotoxic effects of thiazolo[3,2-c] pyrimidines against MCF- 7 and HEPG $2 / C 3 \mathrm{~A}$ cell lines on time-dependent manner (24-, 48- and 72-hour). Further studies on the preparation of more specific thiazolo[3,2-c]pyrimidines, their molecular docking, in vivo and drug targeting research studies are underway in collaboration with other laboratories.

\section{ACKNOWLEDGEMENTS}

The financial supports of Abant Izzet Baysal University, BAP Commission (BAP grant no. 2013.03.03.600 and BAP grant no. 2017.03.03.1218) and TUBITAK (Turkish Scientific and Technological Research Council) (grant no. 113Z012) are gratefully acknowledged.

\section{References}

1. D. Peer, J.M. Karp, S. Hong, O.C. Farokhzad, R. Margalit, R. Langer, Nanocarriers as an emerging platform for cancer therapy, Nat. Nanotechnol., 2 (2007) 751-760.

2. F. Arcamone, Doxorubicin: anticancer antibiotics, (2012) Elsevier, New York, NY, USA.

3. A. Nagy, P. Armatis, A.V. Schally, High yield conversion of doxorubicin to 2-pyrrolinodoxorubicin, an analog 500-1000 times more potent: structure-activity relationship of daunosamine-modified derivatives of doxorubicin, Proceedings of the National Academy of Sciences, 93 (1996) 2464-2469.

4. G. Rodriguez-Berna, M.J.D. Cabañas, V. MangasSanjuán, M. Gonzalez-Alvarez, I. Gonzalez-Alvarez, I. Abasolo, S. Schwartz Jr, M. Bermejo, A. Corma, Semisynthesis, Cytotoxic Activity, and Oral Availability of New Lipophilic 9-Substituted Camptothecin Derivatives, ACS Med. Chem. Lett., 4 (2013) 651-655.

5. M.C. Wani, H.L. Taylor, M.E. Wall, P. Coggon, A.T. McPhail, Plant antitumor agents. VI. Isolation and structure of taxol, a novel antileukemic and antitumor agent from Taxus brevifolia, J. Am. Chem. Soc., 93 (1971) 2325-2327.

6. P.B. Schiff, J. Fant, S.B. Horwitz, Promotion of microtubule assembly in vitro by taxol, Nature, 277 (1979) 665-667.

7. D.B.Longley, D.P. Harkin, P.G. Johnston, 5-fluorouracil: mechanisms of action and clinical strategies, Nature reviews. Cancer, 3 (2003) 330-338.

8. B. Shi, B. Yaremko, G. Hajian, G. Terracina, W.R. Bishop, M. Liu, L.L. Nielsen, The farnesyl protein transferase inhibitor SCH66336 synergizes with taxanes in vitro and enhances their antitumor activity in vivo, Cancer Chemoth. Pharm., 46 (2000) 387-393.

9. O. Cuvillier, V. Nava, S. Murthy, L. Edsall, T. Levade, S. Milstien, S. Spiegel, Sphingosine generation, cytochrome $\mathrm{C}$ release, and activation of caspase- 7 in doxorubicin-induced apoptosis of MCF7 breast adenocarcinoma cells, Cell Death. Differ., 8 (2001) 162-171.

10. F.W. Symmans, Breast cancer response to paclitaxel in vivo, Drug Resist. Update, 4 (2001) 297-302.

11. J. Wichmann, G. Adam, S. Kolczewski, V. Mutel, T. Woltering, Structure-activity relationships of substituted $5 \mathrm{H}$-thiazolo[3,2-a]pyrimidines as group 2 metabotropic glutamate receptor antagonists, Bioorg. Med. Chem. Lett., 9 (1999) 1573-157.

12. F.A. Al-Omary, G.S. Hassan, S.M. El-Messery, H.I. ElSubbagh, Substituted thiazoles V. Synthesis and antitumor activity of novel thiazolo[2,3-b]quinazoline and pyrido[4,3-d] thiazolo[3,2-a] pyrimidine analogues, Eur. J. Med. Chem., 47 (2012) 65-72.

13. S. Fatima, A. Sharma, R. Saxena, R. Tripathi, S.K. Shukla, S.K. Pandey, R. Tripathi, R.P. Tripathi, One pot efficient diversity oriented synthesis of polyfunctional styryl thiazolopyrimidines and their bio-evaluation as antimalarial and anti-HIV agents, Eur. J. Med. Chem., 55 (2012) 195-204.

14. M. Yıldırım, D. Çelikel,Y. Dürüst, D.W. Knight, B.M. Kariuki, A rapid and efficient protocol for the synthesis of novel nitrothiazolo[3,2-c]pyrimidines via microwave-mediated Mannich cyclisation, Tetrahedron, 70 (2014) 2122-2128. 
15. E. Flefel, M. Salama, M. El-Shahat, M. El-Hashash, A El-Farargy, A novel synthesis of some new pyrimidine and thiazolopyrimidine derivatives for anticancer evaluation, Phosphorus Sulfur., 182 (2007) 1739-1756.

16. R. Lin, S.G. Johnson, P.J. Connolly, S.K. Wetter, E. Binnun, T.V. Hughes, W.V. Murray, N.B. Pandey, S.J. Moreno-Mazza, M. Adams, Synthesis and evaluation of 2,7-diamino-thiazolo[4,5-d]pyrimidine analogues as anti-tumor epidermal growth factor receptor (EGFR) tyrosine kinase inhibitors, Bioorg. Med. Chem. Lett., 19 (2009) 2333-2337.

17. B. Singh, S.K. Guru, S. Kour, S.K. Jain, R. Sharma, P.R. Sharma, S.K. Singh, S. Bhushan, S.B. Bharate, R.A. Vishwakarma, Synthesis, antiproliferative and apoptosis-inducing activity of thiazolo[5,4-d] pyrimidines, Eur. J. Med. Chem., 70 (2013) 864-874.

18. T.A.A. Yahya, J.H. Abdullah, M.A.H. Al-Ghorafi, S.H. Yassin, H.M. Almahbshi, Synthesis of some arylidene derivatives of thiazolopyrimidineas anticancer, Der Pharma Chemica, 7 (2015) 106-110.

19. N.A. Abdel-Hafez, S.F. Mohamed, F.A. El-Hag, U.W. Hawas, H.M. Awad, Synthesis and Cytotoxicity Evaluation of Some New Pyrimidinethione and Thiazolopyrimidine Derivatives Linked to N-Propylpiperidone, Der Pharma Chemica, 8 (2016) 57-66.

20. B. Kuppast, H. Fahmy, Thiazolo[4,5-d]pyrimidines as a privileged scaffold in drug discovery, Eur.J. Med. Chem., 113 (2016) 198-213.

21. S. Kolb, O. Mondésert, M.L. Goddard, D. Jullien, B.O. Villoutreix, B. Ducommun, C. Garbay, E. Braud, Development of novel thiazolopyrimidines as CDC25B phosphatase inhibitors, ChemMedChem, 4 (2009) 633-648.

22. A.A. Abu-Hashem, M.M. Youssef, H.A. Hussein, Synthesis, antioxidant, antituomer activities of some new thiazolopyrimidines, pyrrolothiazolopyrimidines and triazolo pyrrolothiazolopyrimidines derivatives, J.Chil. Chem. Soc., 58 (2011) 41-48.

23. M. Yıldırım, D. Çelikel, A rapid access to novel and diverse 3-oxothiazolo[3,2-c]pyrimidine-8carboxylates using multicomponent Mannich cyclisation reactions, Mol. Divers., 19 (2015) 1-13.

24. M. Stojanovi , R. Markovi , E. Kleinpeter, M. BaranacStojanovi, endo-Mode cyclizations of vinylogous $\mathrm{N}$-acyliminium ions as a route to the synthesis of condensed thiazolidines, Tetrahedron, 67 (2011) 95419554.

25. D. Çelikel, Synthesis of new thiazolopyrimidine, thiazolo(imidazolo) pyridinone derivatives via multicomponent reactions M.Sc. Master Thesis, (2015) Abant Izzet Baysal University, Bolu,Turkey.

26. F.P. Karakas, A.B. Yildirim, R. Bayram, M.Z. Yavuz, A. Gepdiremen, A.U. Turker, Antiproliferative activity of some medicinal plants on human breast and hepatocellular carcinoma cell lines and their phenolic contents, Trop. J. Pharm. Res., 14 (2015) 1787-1795.
27. M.M. Kamel, H.I. Ali, M.M. Anwar, N.A. Mohamed, A.M. Soliman, Synthesis, antitumor activity and molecular docking study of novel sulfonamideSchiff's bases, thiazolidinones, benzothiazinones and their C-nucleoside derivatives, Eur. J. Med. Chem., 45 (2010) 572-580.

28. X. Liu, W. Wei, S. Huang, S-S. Lin, X. Zhang, C. Zhang, Y. Du, G. Ma, M. Li, S. Mann, Bio-inspired proteingold nanoconstruct with core-void-shell structure: beyond a chemo drug carrier, J. Mater. Chem. B., 1 (2013) 3136-3143.

29. G.S. Hassan, Synthesis and antitumor activity of certain new thiazolo[2,3-b]quinazoline and thiazolo[3,2-a] pyrimidine analogs, Med. Chem. Res., 23 (2014) 388-401.

30. L. Shen, J. Hu, H. Wang, A. Wang, Y. Lai, Y. Kang, Synthesis and biological evaluation of novel uracil and 5-fluorouracil-1-yl acetic acid-colchicine conjugate, Chem. Res. Chinese. U., 31(2015) 367-371.

31. P.N. Le, N.H. Nguyen, C.K. Nguyen, N.Q. Tran, Smart dendrimer-based nanogel for enhancing 5-fluorouracil loading efficiency against MCF7 cancer cell growth, B. Mater. Sci., 39 (2016) 1493-1500.

32. J.M. Gichumbi, B. Omondi, G. Lazarus, M. Singh, N. Shaikh, H.Y. Chenia, H.B. Friedrich, Influence of Halogen Substitution in the Ligand Sphere on the Antitumor and Antibacterial Activity of Half sandwich Ruthenium (II) Complexes [RuX( 6 arene) (C5H4N2 CH=N Ar)]+, Z. Anorg. Allg. Chem., 643 (2017) 699-711.

33. I.M. Abbas, S.M. Gomha, M.M. Elaasser, B.K. Mabrouk, Synthesis and characterisation of some novel fused thiazolo[3,2-a]pyrimidinones and pyrimido[2,1-b][1,3] thiazinones, J. Chem. Res., 39 (2015) 719-723.

34. S. Awad, O. Fathalla, J. Wietrzyk, M. Milczarek, A. Soliman, M.S. Mohamed, Synthesis of new pyrimidine derivatives and their antiproliferative activity against selected human cancer cell lines, Res. Chem. Intermediat., 41 (2015) 1789-1801.

35. S.M. Rida, S.A. El-Hawash, H.T. Fahmy, A.A. Hazza, M.M. El-Meligy, Synthesis and in vitro evaluation of some novel benzofuran derivatives as potential antiHIV-1, anticancer, and antimicrobial agents, Arch. Pharm. Res., 29 (2006) 16-25.

36. M.M. Mohamed, A.K. Khalil, E.M. Abbass, A.M. ElNaggar, Design, Synthesis of New Pyrimidine Derivatives as Anticancer and Antimicrobial Agents, Synthetic Commun., 47 (2017) 1441-1457. 